\title{
Kajian Kriminologi Terhadap Kekerasan Yang Dilakukan Oleh Perempuan di Kota Ambon
}

\section{Denny Latumaerissa}

\section{dino_elbarca@yahoo.com}

Ilmu Hukum, Fakultas Hukum, Universitas Pattimura

\begin{abstract}
Essentially violent crime can occur wherever, anytime and can be done by anyone without any distinction sex.That is guilty can male or female. Reality that occurs suggests that, female also often perpetrated violent crime. Such as happened in the city of ambon, which according to the data from Polresta P.Ambon and P. P lease, suggests that since 2017 until 2019, there are 14 ( fourteen) violence made by women on jurisdiction. That has been a problem in writing this is what has been factor-factor cause violence carried out by women in the city ambon. Factors influencing the so that a woman committed violence in the city of ambon is the family, the motivation, / sexual disorder of sexual perversion, and the role of the victim
\end{abstract}

\section{Keyword: Criminology, Violence, City Ambon}

\section{PENDAHULUAN}

Kejahatan merupakan sebuah fenomena yang komplek yang sejak dulu terjadi dan tidak dapat dilepaspisahkan dari sebuah peradaban kehidupan masyarakat. Ketidakpuasaan terhadap hukum pidana, hukum acara pidana dan sistem penghukuman serta penerapan metode statistik untuk mengukur angka kejahatan, merupakan faktor-faktor yang memicu perkembangan $\quad$ kriminologi. ${ }^{1}$ Kriminologi adalah ilmu yang mempelajari tentang kejahatan. yang ditemukan oleh seorang ahli antropolog asal Perancis yang bernama $P$. Topinard. $^{2}$ Inti daripada kriminologi adalah mempelajari tentang kajahatan dan mengapa orang melakukan kejahatan.

${ }^{1}$ Topo Santoso dan Eva Achajani, Kriminologi, PT Raja Grafindo Persada, Jakarta, 2003, hal.4

${ }^{2}$ Ibid, hal.9. 
Secara yuridis kejahatan dapat dikatakan sebagai suatu perbuatan melawan hukum. Sebagai akibat dari perbuatannya, maka pelaku kejahatan dapat dikenakan sanksi pidana sebagaimana diatur dalam hukum positif. Dengan demikian, dapat dikatakan bahwasanya suatu kejahatan yang dilakukan oleh seseorang sangat bertentangan dengan hukum. Salah satu jenis kejahatan adalah kejahatan kekerasan.

Kitab Undang Hukum Pidana (selanjutnya disebut KUHP) yang notabenenya merupakan norma umum hukum pidana, didalam rumusannya, tidak ada satupun klausa pasal yang secara ekspilisit menjelaskan tentang defenisi kekerasan, hanya pada pasal 89 KUHP menyebutkan bahwa membuat orang pingsan atau tidak berdaya disamakan dengan menggunakan kekerasan.

$$
\text { Pada dasarnya kejahatan }
$$
kekerasan dapat terjadi dimana saja, kapan saja dan dapat dilakukan oleh siapapun tanpa ada pembedaan jenis kelamin. Artinya pelaku kejahatan bisa laki-laki maupun perempuan. Memang betul jika dilihat dari banyak studi kejahatan berbasis gender seringkali membahas mengenai posisi perempuan sebagai korban dalam sebuah kekerasan. Pembahasan tersebut tidak dapat dilepaskan dari pemikiran tentang posisi inferior dari perempuan jika dibandingkan dengan seorang laki-laki. Mindset tersebut acapkali terpatri didalam benak setiap orang sehingga perempuan tidak pernah dianggap untuk ada pada posisi sebagai orang yang dapat melakukan kejahatan kekerasan, dimana perempuan dipandang sebagai orang yang memiliki sifat penyayang, namun anggapan tersebut tidak dapat dibenarkan. Realita yang terjadi menunjukan bahwa, perempuan juga sering kali menjadi pelaku kejahatan kekerasan.

Misalnya saja yang terjadi di kota Ambon, yang mana berdasarkan data yang diperoleh dari Kepolisian Resort Kota P. Ambon dan P.P Lease (selanjutnya disebut Polresta P. Ambon dan P. P. Lease), menunjukan bahwa sejak tahun 2017 sampai tahun 2019, terdapat 14 (empat belas) kasus kekerasan yang dilakukan oleh perempuan pada wilayah hukumnya. ${ }^{3}$ Seperti contoh pada 2 (dua) kasus yang

${ }^{3}$ Laporan Tahunan Polres Pulau Ambon dan Pulau-Pulau Lease tahun 2019. 
melibatkan perempuan sebagai pelaku kekerasan, yaitu pertama kasus kekerasan terhadap anak yang dilakukan oleh DL terhadap GS (16 tahun) tanggal 23 mei 2019 bertempat didalam Pasar Gudang Arang Kec.Nusaniwe Kota Ambon, sedangkan kasus kedua adalah perkara pencabulan terhadap anak yang dilakukan oleh HB dengan korban FS (13 tahun)

Bertolak dari uraian diatas maka penulis tertarik untuk mengkajinya dalam penulisan ilmiah yang berjudul : KAJIAN KRIMINOLIGI TERHADAP KEKERASAN YANG DILAKUKAN OLEH PEREMPUAN DI KOTA AMBON, dengan permasalahan yaitu faktor-faktor penyebab kekerasan yang dilakukan oleh perempuan di kota Ambon?

\section{PEMBAHASAN}

\section{Kasus-Kasus Kekerasan yang Dilakukan Oleh Perempuan Di}

\section{Kota Ambon}

Ambon adalah sebuah kota di Indonesia Bagian Timur, yang merupakan ibu kota Provinsi Maluku. Kota yang dikenal dengan sebutan "City Of Music" ini terkenal dengan kehidupan masyarakatnya yang sangat ramah. Namun hal ini tidak serta merta menjamin bahwasanya tidak ada kejahatan yang terjadi di kota ini. Sama halnya dengan kota-kota di Indonesia pada umumnya, di Ambon sendiri juga sering kali terjadi kejahatan kekerasan.

Secara umum, ada beberapa jenis/bentuk kejahatan kekerasan, yang akan dijelaskan sebagai berikut: ${ }^{4}$

a. Kekerasan fisik

Kekerasan fisik merupakan perbuatan yang secara fisik menimbulkan rasa sakit pada orang yang menjadi sasaran. Jenis kekerasan ini meliputi menampar, memukul dengan alat, menarik rambut, membanting, mencekik leher, menginjak, dan mendorong kuat-kuat. Kekerasan fisik dapat dilihat dari akibat luka yang ditimbulkan Bekas luka itu dapat di akibatkan oleh rangkaian kekerasan yang tunggal atau berulang-ulang, dari yang ringan hingga yang berat;

b. Kekerasan seksual

${ }^{4}$ Ende Hasbi Nassaruddin, Kriminologi, Pustaka Setia, Bandung, 2016. hal. 135-136 
Kekerasan seksual merupakan setiap perbuatan penyerangan yang bersifat seksual terhadap seseorang, baik telah terjadi persetubuhan atau tidak, dan tanpa memperdulikan hubungan antara pelaku dan korban. Kekerasan seksual tidak terbatas pada perkosaan atau pemaksaan hubungan persentuhan saja, tetapi mencakup juga, berbagai jenis perilaku yang tidak diinginkan oleh korbannya dan bersifat seksual, dan tidak terbatas juga penetrasi alat kelamin laki-laki ke alat kelamin perempuan, tetapi mencakup penggunaan alat atau benda untuk menimbulkan penderitaan pada alat kelamin korban dan bagian-bagian tubuhnya yang lain;

c. Kekerasan Psikologi

Kekerasan psikologi jauh lebih sakit rasanya jika dibandingkan dengan kekerasan fisik, karena jenis kekerasan ini mampu merusak kehormatan orang lain, melukai harga diri seseorang, mengganggu proporsionalitas jiwa, sekalipun tidak merusak organ tubuh atau perbuatan yang dapat menimbulkan kematian. Adapun kekerasan ini meliputi bentakan, makian, penghinaan, sikap merendahkan diri, ancaman untuk menimbulkan rasa takut, larangan untuk berhubungan dengan orang lain, atau bentuk-bentuk pembatasan bergerak lain;

d. Kekerasan ekonomi Jenis kekerasan ini dialami oleh istri bahkan tidak menutup kemungkinan anak dari pelaku turut menjadi korban. Kekerasan ini meliputi memaksa atau melarang istri bekerja untuk memenuhi kebutuhan sehari-hari keluarga, anak di eksploitasi untuk bekerja padahal masih usia produktif untuk sekolah.

Perempuan sebagai pelaku kejahatan kekerasan memang bukan merupakan hal yang lumrah atau biasa terjadi didalam masyarakat. Namun dalam melihat realitas penegakan 
hukum terhadap kejahatan kekerasan, menunjukan bahwa tidak sedikit perempuan yang telah melakukannnya. Kita tidak bisa memungkiri bahwasanya, dewasa ini ada sedikitbanyak pengaruh negatif akibat kesetaraan gender yang selalu disuarakan masif sifatnya ditengahtengah masyarakat. Hal ini ditenggarai sebagai stimulus pada wanita untuk mengambil peran yang sama penting bahkan bisa melebihi peran laki-laki.

Kita bisa lihat bersama, bahwa tidak sedikit perempuan yang berkarier atau sukses baik dalam dunia swasta sebagai pemimpian suatu perusahaan, sampai dengan mengambil bagian sebagai seorang politisi suatu partai politik yang menduduki posisi strategis sampai dengan menjabat sebagai Menteri dalam suatu pemerintahan. Pola-pola kehidupan seperti ini menurut hemat penulis, telah menggiring perempuan untuk ikut aktif pada semua sektor kehidupan publik. Para perempuan berlomba untuk memperoleh penghasilan sendiri sehingga mendapat pengakuan untuk bisa hidup mandiri tanpa ketergantungan dengan suami/orang tua. Hal ini yang menurut penulis, menyebabkan mereka harus dapat berbaur dengan laki-laki tanpa ada batas tempat, waktu, dan lain-lain.

Dampak negatif dari itu semua adalah meluasnya permasalahan yang muncul, antara lain kriminalitas wanita dalam kehidupan umum. Pada awalnya kejahatan yang dilakukan oleh wanita hanya terbatas pada jenis-jenis kejahatan yang berpola "sex-spesific offen" seperti aborsi, dan prostitusi. Namun seiring dengan berkembangan teknologi yang tidak terbendung ini, telah menciptakan kondisi-kondisi sosial seseorang yang memaksa seseorang untuk bertahan pada kondisikondisi tertentu sehingga membuat wanita mulai lazim dengan tindakan kriminal yang biasa dilakukan oleh pria seperti, rentenir, bisnis ilegal narkoba, penipuan, bahkan melakukan kekerasan yang realitanya terjadi hampir di seluruh wilayah Indonesia, tidak terkecuali di kota Ambon.

Untuk mengetahui sejauh mana tingkat perkembangan kejahatan khususnya kejahatan kekerasan dimana pelakunya adalah perempuan di Kota Ambon, maka sebelumnya penulis akan menyajikan data mengenai kekerasan yang dilakukan oleh perempuan yang 
terjadi di Kota Ambon selama kurun waktu tiga tahun terakhir ini, yaitu mulai dari tahun 2017 sampai dengan tahun 2019 dalam bentuk tabel sebagai berikut:

TABEL I

KEKERASAN YANG

DILAKUKAN OLEH

PEREMPUAN DI KOTA

AMBON

\begin{tabular}{|c|c|c|c|}
\hline Tahun & 2017 & 2018 & 2019 \\
\hline Jumlah & $\begin{array}{c}4 \text { (empat) } \\
\text { kasus }\end{array}$ & $\begin{array}{c}5 \\
\text { (lima) } \\
\text { kasus }\end{array}$ & $\begin{array}{c}\text { (lima) } \\
\text { kasus }\end{array}$ \\
\hline Total & 14 Kasus \\
\hline
\end{tabular}

Sumber: Sat Reskrim Polres Pulau Ambon dan P.P Lease

Berdasarkan tabel diatas, terlihat bahwa kekerasan yang dilakukan oleh perempuan di kota Ambon tiap tahunnya relatif meningkat jumlahnya. Untuk tahun 2017 berjumlah 4 (empat) kasus, untuk tahun 2018 meningkat menjadi 5 (enam) kasus, untuk tahun 2019 berjumlah 5 (lima) kasus. Sehingga total jumlah kasus kekerasan yang dilakukan oleh perempuan di kota Ambon dari tahun 2017-2019 berjumlah 14 (empat belas) kasus. Dari jumlah tersebut penulis akan membahas 2 (dua) kasus diantaranya, yakni kasus kekerasan fisik dan kasus kekerasan seksual yang tempus delictinya terjadi pada tahun 2019, dengan kasus posisi yang akan di uraikan oleh penulis sebagai berikut:

\section{Kasus I (Kekerasan fisik (Tindak}

\section{Pidana Kekerasan terhadap Anak))}

- Pada hari kamis 23 Mei 2019, sekitar pukul 19.30 WIT, bertempat di dalam pasar Gudang Arang Kec. Nusaniwe Kota Ambon, saat korban GS (15 tahun) berjenis kelamin laki-laki dan temannya sedang menonton acara perpisahan Pendeta yang mana saat itu keadaan sangat ramai, sehingga korban berdiri di atas tumpukan karung agar bisa melihat acara dimaksud. Ketika korban melompat turun dari atas karung dan membalikan tubuhnya, ternyata ada tersangka DL (31 Tahun) berjenis kelamin perempuan dibelakang korban. Yang mana posisi tersangka juga sedang membalikan tubuhnya, sehingga korban tidak sengaja menyenggol tubuh tersangka; 
- Ketika itu tersangka melihat ke arah wajah korban, dan korban mengatakan "maaf kaka D beta seng sengaja (maaf kk D, saya tidak sengaja)". Namun tersangka emosi dan langsung memukul korban menggunakan kepalan tangan kanan tersangka sebanyak 2 (dua) kali ke belakang kepala korban. kemudian korban dan teman korban berjalan sekitar 3 (tiga) langkah mejauh dari tersangka.

- Ketika korban menengok kebelakang melihat kembali tersangka, tersangka kembali meampar pipi korban menggunakan tepak tangan kanan tersangka sebanyak 1 (satu) kali sehingga korban menangis. Korban pun pulang ke rumahnya dan mengadukan kejadian tersebut kepada kakaknya.

- Karena tidak terima dengan perlakuan tersangka, korban ditemani kakaknya pergi ke rumah tersangka, dan berkelahi dengan tersangka dan keponakan tersangka, dan tersangka mengatakan bahwa korban telah memaki tersangka atas laporan keponakan tersangka, setelah itu tersangka menarik kerak baju korban menggunakan tangan kiri tersangka, namun karena korban berusaha menghindar sehingga jari tangan kanan tersangkka kena pada tengkuk leher korban.

- Sehingga leher korban tercakar oleh tangan kanan tersangka hingga luka lalu tersangka menampar wajah korban lagi sebanyak 1 (satu) kali menggunakan telapak tangan kanan tersangka kena pada pipi kiri korban.

- Setelah itu korban dan kakaknya kembali pulang ke rumah. Selama itu korban dan keluarganya menunggu tersangka untuk meminta maaf dan pihak keluarga korban juga sudah berbicara kepada tersangka, bukannya menyambut baik kedatangan keluarga korban namun tersangka malah marah-marah.

- Perbuatan tersangka tersebut mengakibatkan korban mengalami luka sebagaimana tertuang didalam hasil Visum Et repetum dari Rumah Sakit Bhayangkara Tantui dengan Nomor:VER/82/KES.15/V/Rumkit, tanggal 28 Mei 2019, yang ditandatangani oleh dr, V. T. Larwui, yang menerangkan bahwa korban atas nama GS pada pemeriksaan luar : tampak dua buah luka gores yang susah mengering padal leher bagian depan, ukuran $1,5 \mathrm{~cm}$ dan $2,5 \mathrm{~cm}$, 
dengan kesimpulan luka-luka tersebut diakibatkan oleh benda tumpul. ${ }^{5}$

\section{Kasus II (kasus kekerasan seksual (percabulan terhadap anak))}

- Peristiwa pencabulan dengan tersangka saudari HB alias Glen (32 tahun) dilakukan kepada saksi korban RF (13 tahun) sudah berulang kali, namun seingat saksi korban peristiwa pertama terjadi pada 17 Januari 2017 bertempat di tanah rata kontrakan tersangka tepatnya di ruang tamu saat rumah sedang kosong, dan kejadian terakhir 17 Januari 2019 bertempat di tanah rata tepatnya di kos-kossan tersangka

- Saksi korban pernah mempunyai hubungan pacaran dengan tersangka

- Saksi korban sudah berpacaran dengan tersangka HB selama 1 tahun 10 bulan dari tanggal 17 Januari 2017 sampai dengan bulan Oktober 2018 saksi korban putus dengan tersangka karena selama pacaran saksi korban tidak tahu bahwa jenis kelamin tersangka adalah perempuan

- Selama berpacaran saksi korban tahu tersangka adalah laki-laki, karena tersangka berpenampilan seperti lakilaki, setelah 1 tahun berpacaran barulah saksi korban tahu dari kakak laki-laki tersangka bahwa tersangka adalah perempuan hingga saksi korban memutuskan hubungan dengan tersangka

- Selama berpacaran setiap kali bertemu dengan tersangka, tersangka selalu melakukan pencabulan terhadap saksi korban

- Pertama kali tersangka melakukan pencabulan dengan cara tersangka dan saksi korban berdiri lalu tersangka mencium bibir kemudian menghisap bibir saksi korban sambil tangan tersangka meraba payudara bagian kanan, lalu melanjutkannya dengan meraba payudara bagian kiri saksi korban lalu saksi korban meramas kedua payudara saksi korban secara bersama-sama kurang lebih 5 menit, kemudian tersangka melepaskan kedua tangannya dari payudara saksi korban, lalu tersangka menaikan rok saksi korban sebatas pinggang, tersangka membujuk saksi korban sambil berkata "BETA PEGANG INI (KEMALUAN) SADIKI SA" (saya pegang kemaluan kamu sedikit yach)

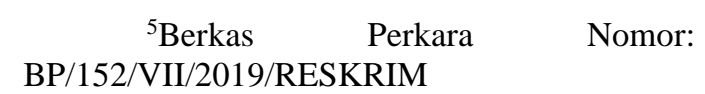


- Namun saksi korban menolak "JANG LAI" (jangan lagi), tetapi tersangka tetap memaksa dan mulai memegang alat kelamin saksi korban menggunakan tangan kiri dan tersangka memasukan kedua jari tersangka kedalam alat kelamin saksi korban lalu memainkan jari tersangka didalam alat kelamin saksi korban sehingga saksi korban berteriak dan menangis karena merasakan kesakitan pada alat kemaluan (saat itu saksi korban tidak melihat jari mana yang dimasukan tersangka didalam alat kemaluan saksi korban, setelah melakukan perbuatan tersebut tersangka menyuruh saksi korban pulang ke rumah.

- Kemudian terakhir tersangka melakukan pencabulan kepada saksi korban dengan cara tersangka menarik tangan saksi korban secara paksa menuju kos-kosan tersangka lalu tersangka memasuka saksi korban kedalam kamar kosan tersangka, kemudian mengunci kamar kosan, ketika saksi korban hendak lari keluar tersangka malah memukul saksi koban dengan kepalan tangan kiri sebanyak 3 (tiga) kali kearah wajah saksi korban nsmun dskdi korban menangkis pukulan tersangka sehingga kena pada kedua tangan saksi korban, lalu tersangka menampar saksi korban menggunakan telapak tangan kiri sebanyak 1 (satu) kali kena pada pipi kanan saksi korban, setelah itu tersangka mendorong saksi korban keatas kasur milik tersangka, dan tersangka secara paksa langsung mencium bibir serta menghisap bibir saksi korban, kemudian tersangka mengangkat rk saksi korban sebatas pinggang dan kembali melakukan pencabulan kepada saksi korban dengan cara memasukan kedua jari tersangka kedalam alat kelamin saksi korban secara paksa sambil memainkan kedua jari tersangka, saat itu saksi korban sempat berteriak minta tolong namun tersangka menutup mulut saksi korban dengan tangan kanan milik tersangka, namun tersangka tetap memainkan jari tersangka sehingga saksi korban menangis karena merasakan sakit pada alat kelamin saksi korban. Saksi korban tidak merasakan ada cairan atau darah yang keluar dari alat kelamin saksi korban saat itu, namun tersangka mengatakan kepada saksi korban bahwa ada cairan berupa darah 
yang keluar pada alatv kelamin saksi korban saat pertama kali tersangka memasukan jari kedalam alat kelamin saksi korban.

- Akibat peristiwa tersebut saksi korban kemudian menjadi takut dan trauma dan juga merasakan sakit di alat kelamin saksi korban

- Perkara pencabulan tersebut bisa diketahui dan kemudian dilaporkan pada hari kamis 14 maret 2019 sekitar Pkl.10.00 WIT, ketikasaksi korban menceritakan semua kejadian tersebut kepada mama saksi korban setelah ibu saksi korban membawa saksi korban ke kantor polisi dan melaporkan perbuatan tersangka. ${ }^{6}$

- Berdasarkan hasil visum et repertum yang dikeeluarkan oleh Rumah Sakit Bhayangkara Tantui Ambon tertanggal 13 Maret 2019, dengan surat permintaan visum et repertum Nomor : R/102/III/2019/SPKT, tanggal 14 Maret 2019, telah dilakukan permintaan pemeriksaan Pencabulan terhadap Anak atas nama korban RF, umur 13 tahun, kelamin perempuan, alamat tanah ratah RT 002/RW 008 Desa Batu Merah Kec.

$\begin{array}{cc}{ }^{6} \text { Berkas } & \text { Perkara } \\ \text { BP/78/IV/2019/RESKRIM }\end{array}$

Sirimau Kota Ambon, yang ditandatangani oleh Pembina dr. V.T Larwuy, dengan hasil yang didapatkan pada pemeriksaan alat kelamin: tempak selaput darah tidak utuh, robekan pada seluruh arah jarum jam, pada arah jam tiga, enam, sembilan, dan dua belas sampai dasar (luka lama)

\section{Faktor-faktor yang mempengaruhi} Kejahatan Kekerasan yang Dilakukan Perempuan di Kota Ambon

Terkait pembahasan mengenai faktor-faktor pencetus kejahatan kekerasan, para ahli krimonologi berpendapat, bahwa dua pertiga kejadian memang didahului oleh adanya hubungan antara pelaku dan korban dalam kejadian tersebut sebelum berlangsungnya kejahatan. Ada kalanya korban memainkan peran positif, namun sering kali korban memainkan peranan kunci dalam interaksi kekerasan, acapkali korban bertindak memprovokasi orang lain atau sering juga mencetuskan saling balas dengan kekerasan yang pada ujungnya berakhir luka atau kematian. 
Untuk itu menurut Shepard, kita hendaknya dapat mendudukkan porsinya masing-masing antara korban dan pelaku, jangan sampai kita menaruh simpati besar pada korban dan kebencian yang berlebihan pada pelakunya. Untuk dapat mengetahui latar belakang mengapa seseorang sampai melakukan kejahatan haruslah didekati dengan multi faktor (Multi Factor Approach) artinya untuk mengetahui kausa kejahatan kita tidak dapat melihatnya hanya pada satu sebab saja yang berdiri sendiri, akan tetapi kita harus melihat dari beberapa faktor yang masing - masing punya peranan dalam terwujudnya kejahatan kekerasan tersebut. ${ }^{7}$

Untuk menjawab permasalahan dalam penelitian ini, maka penulis melakukan wawancara dengan penyidik unit pelayanan Perempuan dan Anak (selanjutnya disebut unit PPA) pada Polresta Kota P. Ambon dan P.P Lease yang menangani 2 (dua) kasus kekerasan yang dilakukan oleh perempuan di kota Ambon, yang secara

\footnotetext{
${ }^{7}$ Abdul Mun'im Idries, dalam Erniwati, Kejahatan Kekerasan Dalam Perspektif Kriminologi,

https://ejournal.iainbengkulu.ac.id/index.php/mi zani/article/viewFile/73/73, diakses 07 April 2020. Pk1.02.05 WIT
}

substansif akan penulis uraikan dibawah ini :

\section{KASUS I}

Kasus dugaan tindak pidana Kekerasan Terhadap Anak di Bawah Umur, dengan tersangka DL terhadap korban GS sehubungan dengan Laporan Polisi Nomor: LP/444/V/2019/Maluku/Res Ambon, yang mana perbuatan tersangka disangkakan melanggar pasal 76c Jo pasal 80 UU Perlindungan Anak, yang berbunyi:

Pasal 76c

Setiap Orang dilarang menempatkan, membiarkan, melakukan, menyuruh melakukan, atau turut serta melakukan kekerasan terhadap Anak.

\section{Pasal 80}

Setiap Orang yang melanggar ketentuan sebagaimana dimaksud dalam Pasal 76C, dipidana dengan pidana penjara paling lama 3 (tiga) tahun 6 (enam) bulan dan/atau denda paling banyak Rp72.000.000,00 (tujuh puluh dua juta rupiah). 
Berdasarkan hasil wawancara penulis dengan penyidik Unit PPA Sat Reskrim Polres Kota P. Ambon dan P. P. Lease, Bripka Doan W. Tehusula ${ }^{8}$ yang menangani kasus ini, didapati bahwasanya alasan atau faktor yang melatarbelakangi sehingga tersangka yang notabenenya berjenis kelamin perempuan melakukan kekerasan terhadap korban anak, adalah tindakan fisik berupa ketidaksengajaan korban menyenggol tubuh tersangka karena keadaan sekitar yang ramai dan didukung juga oleh prasangka tersangka dilecehkan/dimaki oleh korban setelah dipukul oleh tersangka.

Selain itu juga penulis mewancarai tersangka $\mathrm{DL}^{9}$, yang merupakan orang yang diduga melakukan dugaan tindak pidana kekerasan terhadap korban anak GS, sehingga didapati bahwasanya alasan ataupun faktor yang melatarbelakangi sehingga tersangka melakukan perbuatannya adalah karena korban menabrak dirinya dari belakang, karena

${ }^{8}$ Hasil wawancara dengan Bripka Doan W. Tehusula salah satu penyidik Unit PPA Sat Reskrim Polres Kota P Ambon dan P.P Lease, tanggal 02 Maret 2020, Pkl. 15.00 WIT

${ }^{9}$ Hasil wawancara dengan tersangka DL, pada ruang tahanan Polres P. Ambon dan P. P Lease, tanggal 03 Maret 2020, Pkl. 15.30 WIT rasa sakit pada bagian tubuh belakang, sehingga tersangka respon berbalik ke arah korban dan langsung menampar korban sebanyak 1 (satu) kali pada bagian pipi kiri korban.

Setelah itu tersangka lanjut nonton acara perpisahan pendeta hingga selesai. Ketika tersangka dalam perjalanan pulang ke rumah bertemu warga yang mengatakan bahwa korban mengeluarkan kata makian kepada tersangka sehingga tersangka mendatangi korban yang kebetulan berada di depan rumah tersangka dan menampar korban. saat itu korban sempat mengatakan kepada tersangka “tante D ini beta pung pipi sabalah ni tampar lai sudah" (tante D, ini pipi sebelah kanan saya, tampar lagi sudah). Namun tersangka tidak lagi menamparnya dan langsung masuk ke rumahnya.

\section{Kasus II}

Kasus kedua tentang dugaan tindak pidana pencabulan terhadap anak RF yang dilakukan oleh tersangka HB, sehubungan dengan adanya laporan polisi nomor: LP/216/III/2019/Maluku/Res Ambon, 
tanggal 14 maret 2019, yang mana berdasarkan hasil penyelidikan, tersangka disangkakan melanggar pasal 76 Jo pasal 82 Ayat (1) UU RI Nomor 17 tahun 2016 tentang perubahan kedua atas UU RI Nomor 23 tahun 2002 tentang Perlindungan Anak menjadi UU dan atau pasal 292 KUHP, yang masing-masing pasal tersebut berbunyi:

Pasal 76E

Setiap Orang dilarang melakukan Kekerasan atau ancaman Kekerasan, memaksa, melakukan tipu

muslihat,melakukanserangkaian

kebohongan, atau membujuk Anak untuk melakukan atau membiarkan dilakukan perbuatan cabul.

Pasal 82 ayat (1)

Setiap orang yang melanggar ketentuan sebagaimana dimaksud dalam Pasal 76E dipidana dengan pidana penjara paling singkat 5 (lima) tahun dan paling lama 15 (lima belas) tahun dan denda paling banyak Rp 5.000.000.000,00 (lima miliar rupiah).
Pasal 292

Orang dewasa yang melakukan perbuatan cabul dengan orang lain sesama kelamin, yang diketahuinya atau sepatutnya harus diduganya belum dewasa, diancam dengan pidana penjara paling lama lima tahun.

Berdasarkan hasil wawancara penulis dengan penyidik Unit PPA Sat Reskrim Polres Kota P. Ambon dan P. P. Lease, yaitu Bripka O. Jambormias ${ }^{10}$ yang menangani perkara ini, didapati bahwasanya alasan atau faktor yang melatarbelakangi sehingga tersangka melakukan dugaan tindak pidana pencabulan terhadap korban adalah kebutuhan biologis (hasrat tersangka untuk menyalurkan kebutuhan seksual), psikis/psikologis (kelainan seksual/menyukai sesama jenis) dan sosiologis .

Berdasarkan pemaparan dari 2 (dua) kasus diatas, maka penulis berpendapat bahwasanya faktor-faktor yang mempengaruhi sehingga seorang

${ }^{10}$ Hasil wawancara dengan Bripka O. Jambormias, salah satu penyidik Unit PPA Sat Reskrim Polres Pulau Ambon dan P.P Lease, tanggal 02 Maret 2020, Pkl. 16.00 WIT 


perempuan $\begin{aligned} & \text { melakukan } \\ & \text { kekerasan } \\ & \text { kekerasan fisik dan }\end{aligned}$
kekerasan seksual) di kota Ambon
adalah sebagai berikut:

1. Keluarga

Lingkungan keluarga merupakan suatu hal yang mempengaruhi kelanjutan sikap dan cara hidup seseorang (individu), karena lingkungan keluarga sebagai peletak dasar pertama yang mempengaruhi anggota keluarga.. Pengalaman dalam berinteraksi di lingkungan keluarga turut menentukan pula cara - cara tingkah laku seseorang terhadap orang lain dalam pergaulan sosial di luar keluarganya didalam masyarakat umum. Apabila interaksi sosialnya di dalam kelompok, karena berbagai sebab tidak lancar atau wajar, kemungkinan besar bahwa interaksi sosial dengan dengan masyarakat pada umumnya juga berlangsung dalam keadaan tidak wajar. Kurangnya kontrol keluarga tehadap korban khususnya korban anak turut menjadi penyebab anak menjadi korban kekerasan;

2. Motivasi Pelaku

Kejahatan kekerasan yang dilakukan oleh perempuan, terkadang merupakan upaya untuk mempertahankan diri tidak dengan perencanaan terlebih dahulu, artinya kekerasan tersebut merupakan respon pelaku akibat kondisi tertentu (adanya tekanan besar) diskitar pelaku yang langsung berkaita dengan pelaku. Selain itu juga motifasi pelaku untuk memperoleh kesenangan atau kepuasaan sendiri, sehingga memungkinkan individu untuk melakukan suatu kejahatan;

3. Kelainan seksual/penyimpangan seksual Pelaku memiliki kesamaan pola perilaku, yaitu pelaku memiliki penyimpangan seksual, rentang usia pelaku dengan korban; kedekatan secara fisik dan tempat tinggal, bujuk rayu, paksaan, tipu muslihat atau janji-janji imbalan; 
4. Peran korban

Kejahatan kekerasan kadang

didahului oleh adanya

hubungan yang terbangun

antara pelaku dan korban.

Dalam kejadian tersebut

sebelum berlangsungnya

kejahatan, ada kalanya korban

memainkan peran positif, namun

sering kali juga korban

memainkan peranan kunci

dalam interaksi kekerasan.

Atau dengan kata lain ada

sedikit banyak andil dari pihak

korban sebagai pencetus

kejahatan. Kerugian akibat

tindak pidana kejahatan

kekerasan sebenarnya tidak

terjadi bila tidak ada provokasi

dari si korban. Sehingga

peranan korban dalam suatu

tindakan kekerasan tidak bisa

dikesampingkan.

Jika dicermati dari berbagai faktor diatas maupun penjelasan sebelumnya, mulai dari kronologis tindak pidana atau kasus posisi yang di uraikan, serta hasil wawancara penulis dengan tersangka maupun penyidik yang menangani 2 (dua) perkara tersebut, maka berkaitan dengan penulisan ini terkait faktor-faktor perempuan sebagai pelaku kekerasan di Kota Ambon yang di dapatkan tersebut sejalan dengan teori kriminologi yang penulis gunakan sebagai pisau analisis dalam menjawab permasalahan yaitu Teori Anomie dari K Merton.

Konsep Merton tentang Anomie berbeda dengan apa yang digunakan oleh Durkheim, yang memberi batasan Anomie sebagai suatu keadaan tanpa norma atau tanpa harapan (Normless). Tipologi. Merton tentang adaptasi pada Anomie dikenal sebagai teori ketegangan. Teori ini menganggap bahwa kejahatan muncul sebagai akibat apabila individu tidak dapat mencapai tujuan-tujuan mereka.melalui saluran legal atau menarik diri dari pergaulan sosial karena kemarahannya. Pada dasarnya semua individu memiliki kesadaran hukum dan taat pada hukum yang berlaku, namun pada kondisi tertentu (adanya tekanan besar), maka memungkinkan individu untuk melakukan suatu kejahatan. Keinginan yang cukup besar untuk meningkat 
secara sosial (social mobility) membawa pada penyimpangan. ${ }^{11}$

\section{PENTUP}

\section{Kesimpulan}

Terkait pembahasan mengenai faktor-faktor pencetus kejahatan kekerasan, para ahli krimonologi berpendapat, bahwa dua pertiga kejadian memang didahului oleh adanya hubungan antara pelaku dan korban dalam kejadian tersebut sebelum berlangsungnya kejahatan. Ada kalanya korban memainkan peran positif, namun sering kali korban memainkan peranan kunci dalam interaksi kekerasan, acapkali korban bertindak memprovokasi orang lain atau sering juga mencetuskan saling balas dengan kekerasan yang pada ujungnya berakhir luka atau kematian Perempuan sebagai pelaku kejahatan kekerasan memang bukan merupakan hal yang lumrah atau biasa terjadi didalam masyarakat. Namun dalam melihat realitas penegakan hukum terhadap kejahatan kekerasan, menunjukan bahwa tidak sedikit perempuan yang telah melakukannnya. Faktor-faktor yang mempengaruhi sehingga seorang perempuan melakukan tindakan kekerasan di kota Ambon adalah faktor keluarga, motivasi Pelaku, kelainan seksual/penyimpangan seksual, serta peran korban

\section{Saran}

Diperlukan peran aktif dari semua stakeholder untuk dapat mencegah perempuan melakukan tindakan kekerasan yang dapat dimulai dari dalam keluarga sebagai unit kecil dalam masyarakat, masyarakat secara luas, serta aparat penegak hukum untuk saling bersinergi dalam melakukan langkah-langkah preventif. Misalnya fungsi kotrol keluarga sebagai peletak dasar pertama yang mempengaruhi anggota keluarga dalam berinteraksi dengan masyarakat harus dijalankan secara baik.

\footnotetext{
${ }^{11}$ Alam A. S, Pengantar Kriminologi, Pustaka Refleksi, Makasar, 2010, hal. 41.
} 


\section{Daftar Pustaka}

Achajani, T. S. (2003). Kriminologi. Jakarta: PT Raja Grafindo Persada.

Nassaruddin, E. H. (2016). Kriminologi. Bandung: Pustaka Setia.

S, A. A. (2010). Pengantar Kriminologi. Makassar: Pustaka Refleksi.

\section{Lain-lain:}

Berkas Perkara Nomor: BP/152/VII/2019/RESKRIM

Berkas Perkara Nomor : BP/78/IV/2019/RESKRIM

Kitab Undang-Undang Hukum Pidana

Erniwati, Kejahatan Kekerasan Dalam Perspektif Kriminologi, https://ejournal.iainbengkulu.ac.id/index.php/mizani/article/viewFile/73/73

Laporan Tahunan Polres Pulau Ambon dan Pulau-Pulau Lease tahun 2019 